EUROPEAN HONORS COUNCIL

Note

\title{
Excellence in Arts Education: A Benchmark Research
}

\author{
Mariska Versantvoort
}

Willem de Kooning Academy, Rotterdam University of Applied Sciences, Rotterdam, the Netherlands ${ }^{1}$

\section{Correspondence: Mariska.Versantvoort@warwick.ac.uk}

Received: 3 September 2019; Accepted: 14 October 2019; Published: 11 November 2019

Keywords: art education, benchmark, international perspectives

\section{Introduction: A Paradox}

At the Willem de Kooning Academy in Rotterdam (the Netherlands), we have been struggling for some time now with the questions: How does the honours programme ${ }^{2}$ distinguish itself from the regular curriculum? Art education specialises in talent development, unlike the majority of higher education programmes. Students are selected at the gate on their visual skills and creative capacity. Likely as a result of this unique position, my colleagues and I experience that our students have an above average level of intrinsic motivation and task dedication - two defining characteristics of excellent students - when compared with their peers at other institutes. Though this seems to suggest that all our students are potential honours students, in practice we do observe the need for greater differentiation. Here we arrived at a paradoxical question: How is it possible to design honours education for specifically-talented students? Notably, no literature could be found on this subject.

The research therefore had a threefold aim: 1) to create a frame of reference for honours and/or excellence in arts education; 2 ) to visualise the position of the honours programme at the Willem de Kooning Academy vis-à-vis its discipline-specific partners in the Netherlands as well as abroad; and 3 ) to create a tentative understanding of the authenticity of honours education in the arts.

\section{Methodology and Limitations}

In order to gain insight into the field of honours education at universities for the arts, a benchmark research study was carried out. In this research, the websites of Dutch universities for the arts were compared with those from art academies, conservatories, and institutes for performing arts in the United States. The choice for conducting a comparative 
analysis between the Netherlands and the US was based on a limitation found with regard to the initial research premise, which is explained in the next paragraph. With regard to the latter a selection was made to create a sample size numerically similar to the Netherlands. Institutes were compared and contrasted based on key words in their texts as well as on their statements regarding the characteristics of the honours student and the didactics of the programme (see: Wolfensberger, 2012, p. 23-46; Kazemier et al., 2014; and, Tiesinga \& Wolfensberger, 2014, p. 14). The result is an inventory on the current state of honours programmes in arts education.

There are three notable limitations to the scope of this research. First of all, the study did not engage with any explanatory literature in order to interpret its results. Secondly, it was initially designed to include European as well as non-Western universities for the arts. Within the partner network of the Willem de Kooning Academy, however, no such institutes were found to have honours programmes, or their websites were inaccessible as a result of language barriers. Universities in the United Kingdom were excluded from the survey. In the UK, honours degrees are primarily awarded on the basis of a student's grade average. The recent concerns raised by the UK Secretary of Education Damian Hinds regarding the inflation of these grades arguably call into question the standing of UK honours trajectories (Department of Education, 2019). They have therefore not been taken into consideration. Lastly, in order to create the sample of American universities, data were used from the QS World University Ranking, as well as niche.com (Colliers, 2019) and onestageblog.com (Peterson, 2018). Multiple sources were consulted because there seems to be no single authoritative ánd representative list available on all these disciplines.

\section{Findings}

To start with numbers: In the Netherlands, 4 out of 10 public art academies facilitate an honours programme, compared to only one conservatory, and none of the departments for dance or theatre. In the United States, 6 of the 16 researched art academies provide an honors program, with 2 academies more offering a course closely related to honours education. In addition, 4 of the 10 researched American conservatories and theatre schools have an honors trajectory. And, lastly, 3 out of 10 dance academies state an honors program on their website (see table 1). With regard to the latter two, however, all except one university refer to a university-broad programme that is neither further elaborated upon nor in any way specific to theatre or dance education. These have therefore not been taken into account for the analysis.

Within music education, "honours" or "excellence" seems to be exclusively reserved for student musicians who excel in their discipline. It is used to qualify results rather than to analyse and act upon successful study behaviour. Students who show to be exceptionally gifted receive additional coaching, are given opportunities to perform in public, or can continue their studies in a master programme. Descriptions on the websites are brief and mainly list criteria students must meet in order to be selected. Though the texts suggest that successful competitors for the two honours ensembles must also have good collaborative skills and an entrepreneurial attitude, no specific characteristics of either the student or the programme didactics are mentioned explicitly on any of the websites. An exception to this rule is the Prince Claus Conservatory in the Netherlands - see table 2. This institute provides 
motivated students with an interdisciplinary trajectory that challenges the young musicians to situate their practice with a broader societal context.

With regard to art and design education, universities in the Netherlands emphasize a student's motivation over grade point averages or other formal requirements. The didactics of the programmes focuses, by extent, on building a community of students with similar levels of intrinsic motivation and task dedication as well as deepening academic competence - see table 4. American universities, on the other hand, say little to nothing about the characteristics of the students they seek to educate. Instead the content of their curriculum is placed in the limelight. The orientation of these academic programmes is split between universities that offer their students an accelerated or advanced theory course versus those who provide unique opportunities for further professional training, such as field trips or a residency programme - see table 3 . Another key difference is the fact that in the United States honors programs are fully embedded within the regular curriculum, whereas most Dutch students still partake in it as an extra-curricular activity. What the descriptions of honours programmes in both countries have in common, though, is that these texts neither elaborate on the institute's core values and objectives - as is common for university colleges, the archetypical honours programmes - nor expand upon the impact of the programme on the careers of graduates. To note, 3 out of 5 Dutch academies mention, in a few words, that honours students can continue their studies at master level, versus 2 out of 8 American institutes. However, no proof of effect is provided.

Notably, only few universities give a definition of cleverness - the integration of analytical ability, creativity, and practical intelligence (Wolfensberger, 2012, p. 48), a student's need for self-management, and what Wolfensberger coined the didactics of "bounded freedom" (ibid, p. 117-118). OTIS College of Art and Design explicitly addresses "cleverness" in their academic core, which exists of a studio 'foundation', a 'liberal arts and sciences' theory programme, and 'creative action'. All aspects are mirrored and enhanced in the objectives of their honors program. The so-called Practices at the Willem de Kooning Academy have a similar potential, which is not yet utilised in their honours programme. Bounded freedom, in turn, is most recognisably provided through having students write their own learning plan. It is however not possible to assess the full extent of this characteristic as none of the universities' descriptions elaborate in detail on their didactics.

Zooming in on the Netherlands, all academies state that their honours course is interdisciplinary. The scope thereof notably differs from offering an interdepartmental programme to collaborating with students from disciplines outside the humanities. Here too the academic content of the programme seems to be split, in this case, between providing an advanced theory course and working on so-called wicked problems in a societal context. Though honours programmes in The Netherlands are often seen as laboratories for educational innovation (Weerheijm, Veenstra \& Ter Woord, 2015, p. 2), only Gerrit Rietveld Academy names it as one of the defining characteristics albeit in relation to their content rather than didactics. All programmes are a collaborative endeavour with a so-called centre of expertise, which are research groups at Dutch universities of applied sciences. 


\section{Preliminary Observations}

As stated above, this research had the aim to create a first inventory of honours programmes at universities for the arts, rather than to elaborate upon, scrutinize, or explain its findings. There is nevertheless a preliminary observation that can be made from the data gathered. Although the initial premise of this study suggested that there would be an intrinsic difference between honours education at universities for the arts and institutes that do not preselect their students on the basis of a specific talent, there is no information found that would support such a presupposition. The descriptors that art academies and institutes for performing arts use to promote their honours programmes do not present anything that is out of the ordinary with the general theory on the subject - regardless of reservations on the level of implementation of various elements. There is a notable distinction between institutes that interpret excellence as successful study behaviour and those that see excellence as something that can be measured through grades and discipline-specific achievements. Hence, insofar as "excellence" and "talent development" are an on-going conversation within educational practice that is focused on a student's behaviour, universities for the arts seem to abide by the same paradigm as other educational institutes.

\section{Concluding Remarks for Further Research}

The initial research question driving this study still stands: How is it possible to design honours education for specifically-talented students? This benchmark has been a first attempt to fill what seems to be a void in the existing literature on excellence. This note is therefore an invitation to others to share their knowledge on honours education in the context of art, design, music, dance, and theatre. One way forward is to look into the successes of our honours programmes; what are the effects of honours education on our students' learning outcomes and their professional careers? In other words, to what extent is "excellence" in arts education making a difference?

\section{Acknowledgments}

The author would like to thank Karin Hillen and Sylvia Erlings for their contributions to the research and their critical feedback.

\section{References}

2020 Best Colleges for Music in America. (2019). Retrieved from: niche.com (accessed August 2019)

Collier, S. (2019, February 27). Top Art \& Design Schools in 2019. Retrieved from:

topuniversities.com (accessed July 2019)

Department of Education (2019). Universities to end grade inflation. Retrieved from: gov.uk (accessed 3 October 2019)

Kazemier, E., Offringa, J., Eggens, L., \& Wolfensberger, M. (2014). Motivatie, leerstrategieën en voorkeur voor doceerbenadering van honoursstudenten in het hbo. Tijdschrift voor Hoger Onderwijs, 4(1), 106-124, doi: 10.5553/TvHO/016810952014032001009 
Peterson, C . (2018, August 21). The Top 25 College Dance Programs for 2018-2019.

Retrieved from: onstageblog.com (accessed August 2019)

Peterson, C. (2018, August 27). The Top 25 BFA Acting/ Performance Programs for 20182019. Retrieved from: onstageblog.com (accessed August 2019)

Tiesinga, L., \& Wolfensberger, M. (2014). De cultuur van honoursstudenten en de mogelijke invloed op de reguliere studiecultuur. Tijdschrift voor Hoger Onderwijs 31, 5-19. doi:10.5553/TvHO/016810952014032001002

Weerheijm, R., Veenstra, P., \& Ter Woord, R. (2015). Beleidsnotitie excellentie- en honoursonderwijs: De volgende fase. Retrieved from: vereniginghogescholen.nl (accessed 4 June 2018)

Wolfensberger, M. V. C. (2012). Teaching for Excellence: Honours Pedagogies Revealed. Münster: Waxmann. 
Table 1: List of Universities

\begin{tabular}{|l|l|}
\hline Colour Coding Explained \\
\hline & The university states an honours programme on their website. \\
\hline $\begin{array}{l}\text { The university does not state an honours programme on their website, but } \\
\text { does provide a trajectory similar or partial to such a programme. }\end{array}$ \\
\hline $\begin{array}{l}\text { The university facilitates students from non-art disciplines to enrich their } \\
\text { studying by partaking in art classes. }\end{array}$ \\
\hline
\end{tabular}

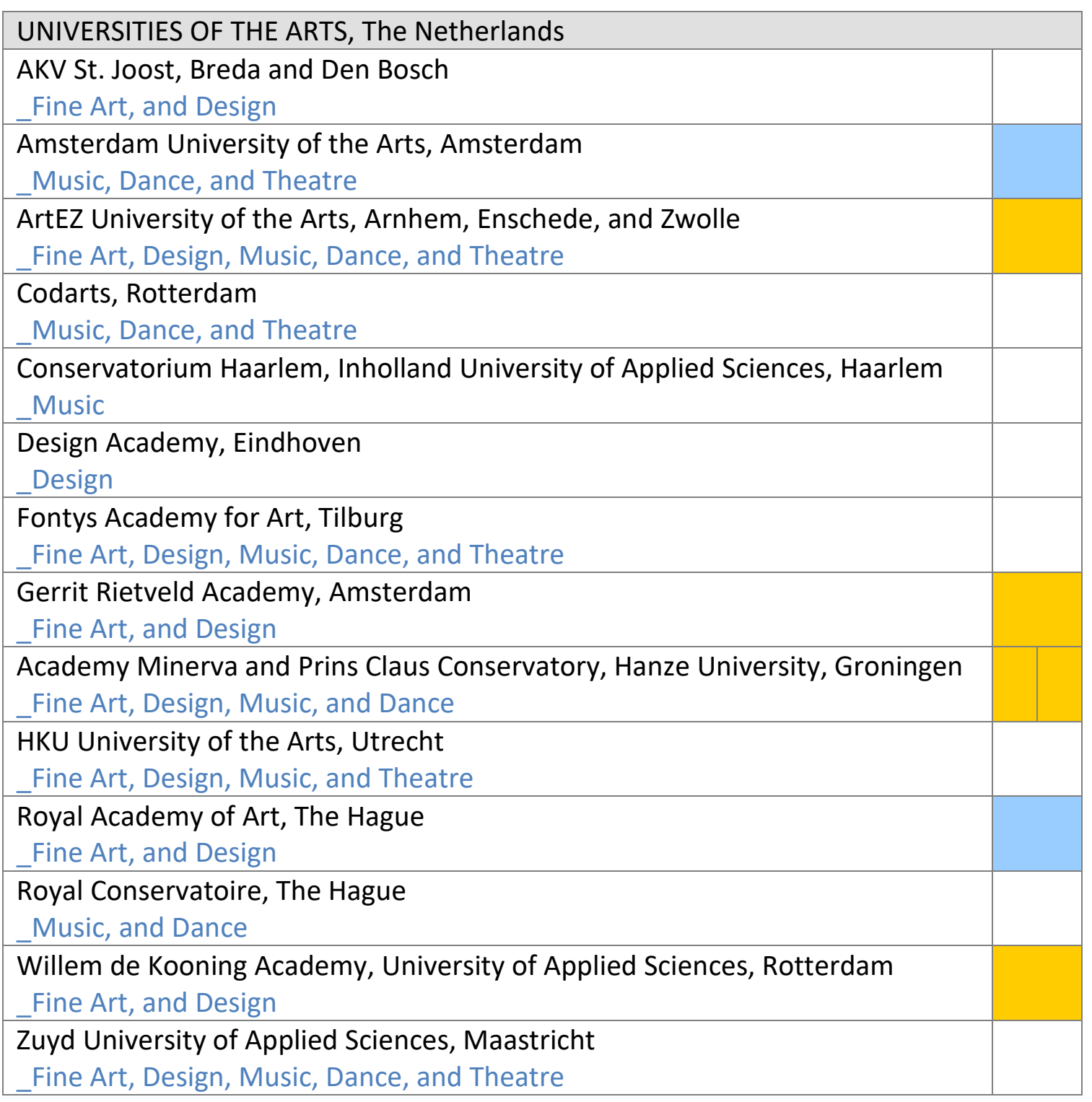

\begin{tabular}{|l|l|}
\hline ART UNIVERSITIES, United States of America (partner institutes of the WdKA) \\
\hline Maryland Institute College of Art, Baltimore & \\
_Fine Art and Design & \\
\hline Massachusetts College of Art and Design, Boston \\
Design, incl. Liberal Arts
\end{tabular}


OTIS College of Art and Design, Los Angeles

Fine Art, and Design, incl. Liberal Arts and Sciences

Ringling College of Art and Design, Sarasota

Fine Art, and Design, incl. Liberal Arts

24. School of Visual Arts, New York

Fine Art, and Design

The Art Institute of Boston, Lesley University, Boston

Fine Art, Design, and Liberal Arts and Sciences

ART UNIVERSITIES, United States of America (QS World University Ranking 2019)

03. Parsons School of Design at The New School, New York City

Fine Art, and Design, incl. Liberal Arts

04. RISD Rhode Island School of Design, Providence

Fine Art, and Design, incl. Liberal Arts

05. MIT Massachusetts Institute of Technology, Cambridge

Music, and Theatre

09. SAIC School of the Art Institute of Chicago

Fine Art, Design, and Liberal Arts

10. Pratt Institute, New York City

Fine Art, Design, and Liberal Arts and Sciences

13. Art Center College of Design, Pasadena

Fine Art, and Design

14. Stanford University

Fine Art, Music, Dance, and Theatre

17. Carnegie Mellon University, Pittsburgh

Fine Art, Design, Music, and Theatre

21. California Institute of the Arts, Santa Clarita

Fine Art, Design, Music, Dance, and Theatre

22. California College of the Arts, San Francisco and Oakland

Fine Art, and Design

CONSERVATORIES, United State of America (niche.com)

01. The Curtis Institute of Music, Philadelphia

02. Berklee College of Music, Boston

03. The Juilliard School, New York

04. The New England Conservatory of Music

Honors Ensemble

05. University of Southern California, Los Angeles

06. Blair School of Music, Vanderbilt University, Nashville

07. San Francisco Conservatory of Music, San Francisco 
08. Bienen School of Music, Northwestern University, Evanston

Vocal Honors Program

09. The Shepherd School of Music, Rice University, Houston

5 Year Honors Program

10. Peaboy Institute, Johns Hopkins University, Baltimore

Honors Ensemble

\begin{tabular}{|l|l|}
\hline DANCE ACADEMIES, United States of America (onstageblog.com) & \\
\hline 01. NYU Tisch School of the Arts, New York & \\
\hline 02. The Ailey School, Fordham University, New York & \\
\hline $\begin{array}{l}\text { 03. Ann Lacy School of Dance and Entertainment, Oklahoma City University } \\
\text { _Honors Program (general) }\end{array}$ & \\
\hline $\begin{array}{l}\text { 04. The Juilliard School, New York } \\
\text { _Honors Program (general) }\end{array}$ & \\
\hline $\begin{array}{l}\text { 06. Jordan College of the Arts, Butler University, Indianapolis } \\
\text { Honors Program (general) }\end{array}$ & \\
\hline 07. Meadows School of the Arts, Southern Methodist University, Dallas \\
\hline \begin{tabular}{l} 
08. University of North Carolina School of the Arts, Winston Salem \\
\hline $\begin{array}{l}\text { 09. University of Arizona School of Dance, Tucson } \\
\text { Honors College (general) }\end{array}$
\end{tabular} \\
\hline 10. The Sharon Disney Lund School of Dance, California Institute of the Arts \\
\hline
\end{tabular}

\begin{tabular}{|l|l|}
\hline THEATRE SCHOOLS, United States of America (onstageblog.com) & \\
\hline 01. The Juilliard School, New York & \\
\hline 02. USC School of Dramatic Arts, Los Angeles & \\
\hline $\begin{array}{l}\text { 03. The Theatre School, DePaul University, Chicago } \\
\text { _Honors Program (general) }\end{array}$ & \\
04. NYU Tisch School of the Arts, New York \\
_The Honors Program in Theatre Studies \\
\hline $\begin{array}{l}\text { 05. The University of Miami, Coral Gables } \\
\text { The Honors Program (general) }\end{array}$ \\
\hline \begin{tabular}{l} 
06. Actors Studio Drama School, Pace University, New York \\
\hline 07. Syracuse University, New York \\
Renée Crown University Honors Program (general)
\end{tabular} \\
\hline 08. Boston University & \\
\hline
\end{tabular}


Page 9 of 12

09. The University of Creative Careers, Savannah

10. Carnegie Mellon University, Pittsburgh 
Table 2: Profile of Honours Programmes at Dutch Universities for the Arts

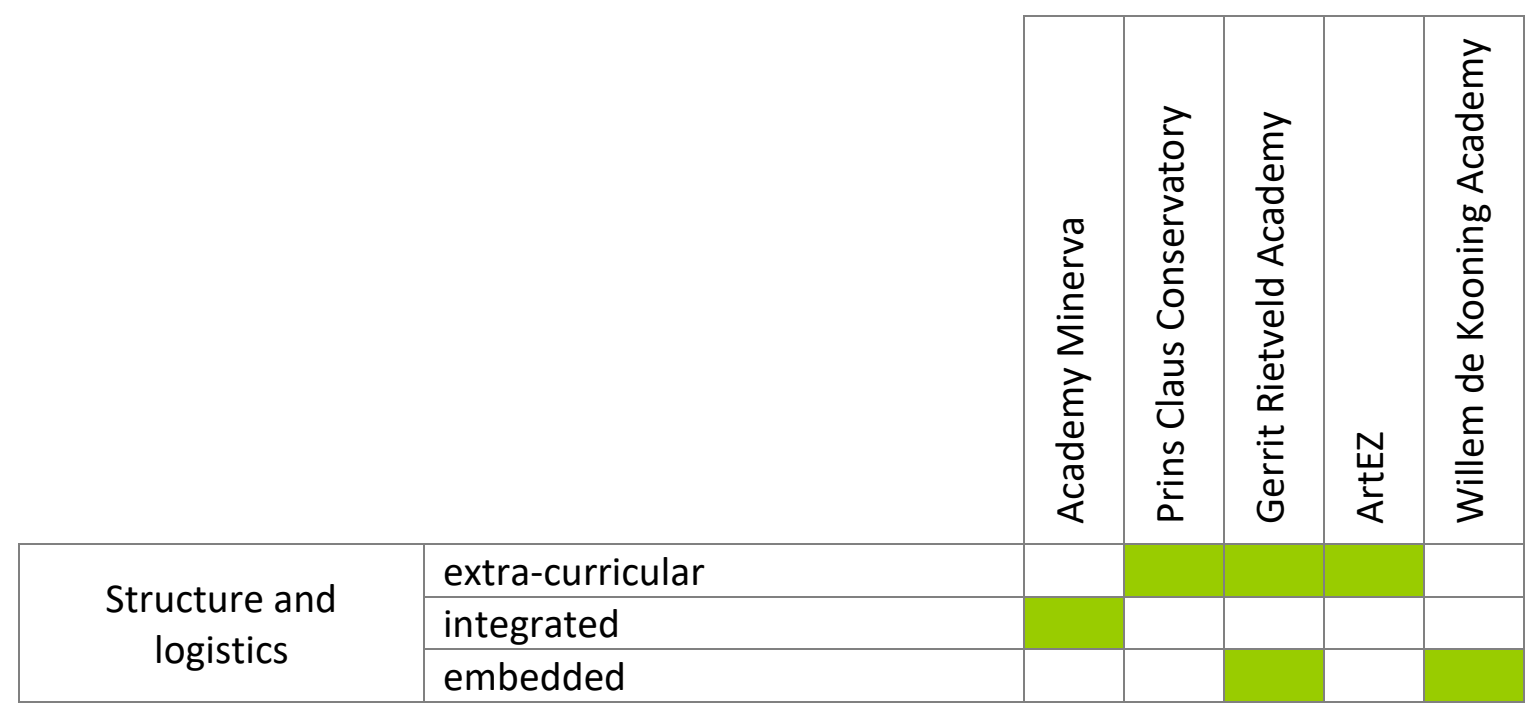

\begin{tabular}{|l|l|l|l|l|l|}
\hline \multirow{4}{*}{ Content and form } & inter- and/or multidisciplinary & & \\
\hline & theory & & \\
\hline & research & & & \\
\hline & societal issues & & & & \\
\hline & innovation & & & & \\
\hline
\end{tabular}

\begin{tabular}{|l|l|l|l|l|l|}
\hline \multirow{3}{*}{ Partners } & research centre & & & & \\
\hline & universities & & & & \\
\hline & societal partners & \\
\hline
\end{tabular}

\begin{tabular}{|l|l|l|l|l|l|}
\hline \multirow{3}{*}{ Selection } & motivation & & & & \\
\hline & learning plan & & & \\
\hline & (artistic) vision & & & \\
\hline & competencie: creative ability & & & & \\
\hline & leadership & & & & \\
\hline & referent & & & & \\
\hline & grade average & & & \\
\hline
\end{tabular}

Future perspective master

\begin{tabular}{|l|}
\hline Colour Coding Explained \\
\hline $\begin{array}{l}\text { The university explicitly states the characteristic in some detail on their } \\
\text { website. }\end{array}$ \\
$\begin{array}{l}\text { The university mentions the characteristic, but either does not elaborate on it } \\
\text { or arguable does not utilise it to its full scope as described in the literature. }\end{array}$ \\
\hline
\end{tabular}


Table 3: Profile of Honours Programmes at American Universities for the Arts

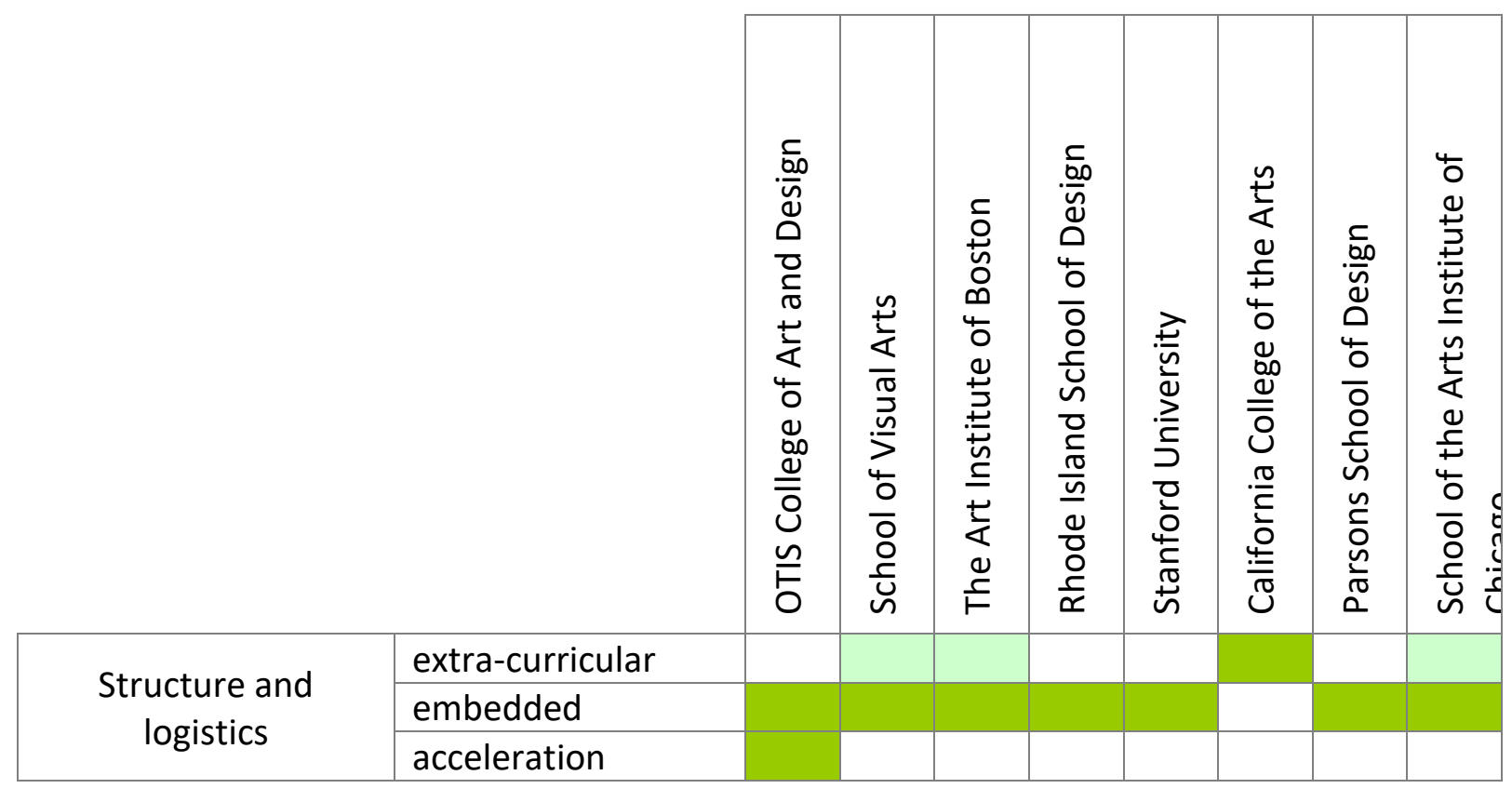

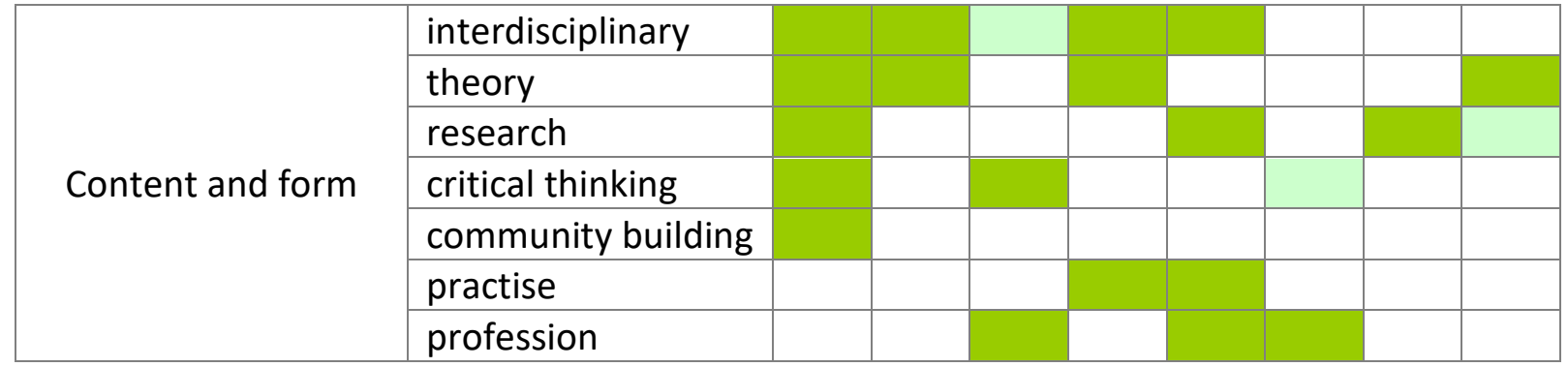

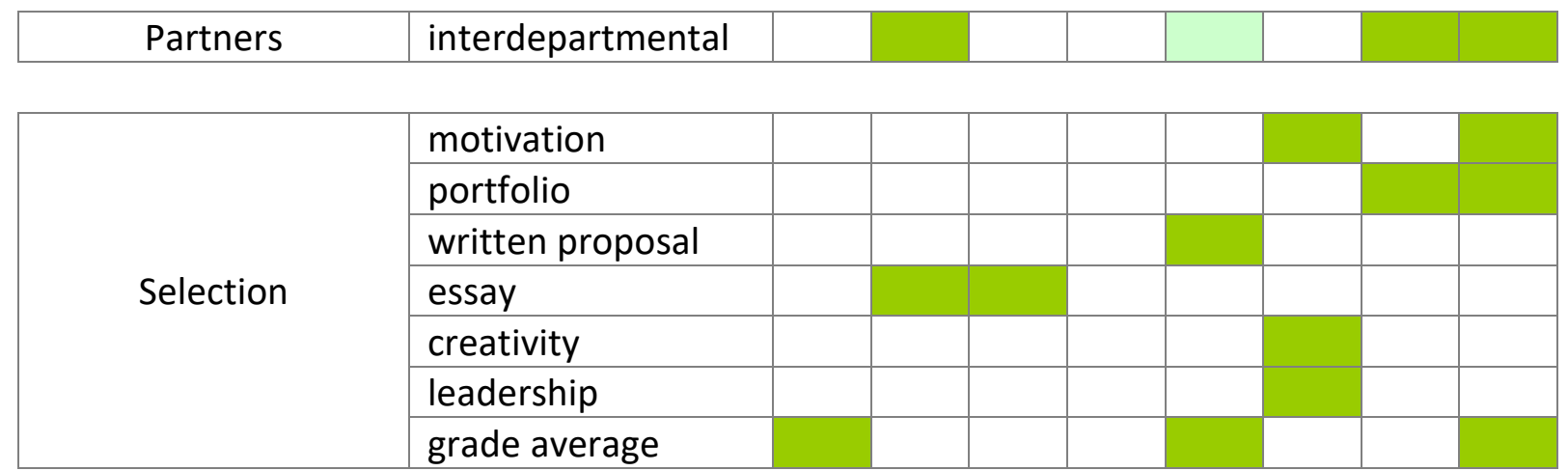

Future perspective $\quad$ master

\begin{tabular}{|l|l|}
\hline Colour Coding Explained \\
\hline $\begin{array}{l}\text { The university explicitly states the characteristic in some detail on their } \\
\text { website. }\end{array}$ \\
$\begin{array}{l}\text { The university mentions the characteristic, but either does not elaborate on it } \\
\text { or arguably does not utilise it to its full scope as described in the literature. }\end{array}$ \\
\hline
\end{tabular}


Table 4: Positioning of Universities of the Arts in relation to the Literature on Excellence

\begin{tabular}{|l|}
\hline Academy Minerva (Hanze) \\
\hline Prins Claus Conservatory (Hanze) \\
\hline Gerrit Rietveld Academy \\
\hline ArtEZ \\
\hline Willem de Kooning Academy \\
\hline
\end{tabular}
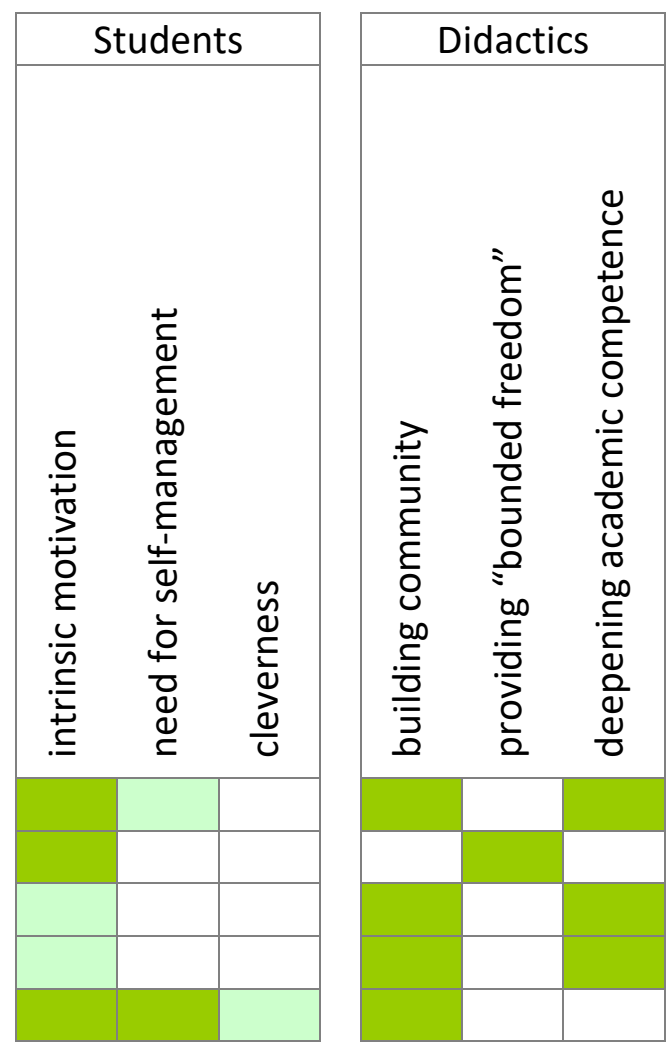

\begin{tabular}{|l|}
\hline OTIS College of Art and Design \\
\hline School of Visual Arts \\
\hline The Art Institute of Boston \\
\hline Rhode Island School of Design \\
\hline Stanford University: Honors in the Arts \\
\hline Stanford University: Honors in Art Practice \\
\hline California College of the Arts \\
\hline Parsons School of Design \\
\hline School of the Art Institute of Chicago \\
\hline
\end{tabular}
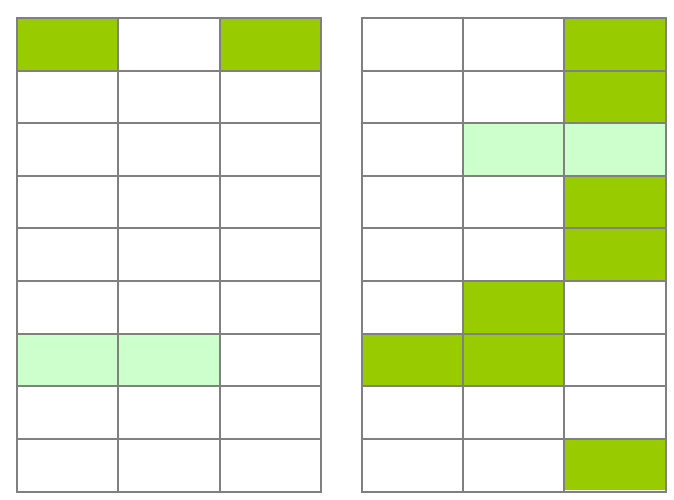

\begin{tabular}{|l|}
\hline Colour Coding Explained \\
$\begin{array}{l}\text { The university explicitly states the characteristic in some detail on their } \\
\text { website. }\end{array}$ \\
$\begin{array}{l}\text { The university mentions the characteristic, but either does not elaborate on it } \\
\text { or arguable does not utilise it to its full scope as described in the literature. }\end{array}$ \\
\hline
\end{tabular}

\footnotetext{
${ }^{1}$ At the time of research and writing, Mariska Versantvoort was the coordinator of the Honours Programme at the Willem de Kooning Academy in Rotterdam (The Netherlands). Currently, she is working as a Ph.D. Candidate in the Department of Politics and International Studies at the University of Warwick (United Kingdom).

${ }^{2}$ Insofar as universities in the Netherlands abide by British spelling in their website descriptions, I use "honours programme" to refer to Dutch curricula and "honors program" when speaking of their US equivalents.
} 